\title{
PROCESSOS DISCIPLINARES E TRABALHO DOCENTE NA ESCOLA PRIMÁRIA DE MINAS GERAIS (1869-1890)
}

\section{Sarah Jane Alves Durães*}

RESUMO: O presente artigo analisa 23 processos disciplinares contra professores e professoras das escolas públicas primárias durante a segunda metade do século XIX. A instauração desses processos e as suas consequências serviram como ações disciplinares e disciplinadoras por parte do Governo Mineiro e, para tanto, este contava com uma série de regulamentos que prescreviam práticas de inspeção e códigos disciplinares de ordem moral e/ou pedagógica. A cargo dos membros que faziam parte da Comissão do Conselho Diretor do Governo Mineiro ficava a responsabilidade por averiguar e punir aqueles professores e professoras que cometiam infrações como, por exemplo, negócios estranhos ao magistério, desempenho insatisfatório do trabalho docente e práticas que, segundo a legislação, não condiziam com a moral exigida ao cargo. Quando comprovado o descumprimento da lei, o docente ficava sujeito a suspensão, remoção ou demissão do magistério.

Palavras-chave: Processo Disciplinar; Escola Primária; Trabalho Docente.

\section{DISCIPLINARY PROCESSES AND TEACHER WORK IN THE PRIMARY SCHOOL OF MINAS GERAIS/BRAZIL (1869-1890)}

ABSTRACT: This article analyzes 23 disciplinary processes and its results which were used as disciplinary actions of the teacher's work by the Government of Minas Gerais/Brazil in the primary school during the second half of the nineteenth century. Although some of those strategies were just attempts, the Government proposed many laws intending to control the teacher's work in the whole province/state. The Director Council members had the function of investigating and punishing the male and female teachers who had done some labors that were different from the teacher's work, they had an unsatisfactory performance of teaching and had some moral behaviors that were not suitable for the office. Through a disciplinary process, the Government had the criterion and large legislation that punished the teacher with a temporary stoppage without payment, with a cast out from his/her space or with the definitive loss of his/her permission to teach in primary schools.

Keywords: Disciplinary Process; Primary School; Teaching Work.

*Doutora em Educação pela Pontifícia Universidade Católica de São Paulo e Professora da Universidade Estadual de Montes Claros. E-mail: sj-duraes@uol.com.br. 
O Poder Público Mineiro, no transcurso da segunda metade do século XIX, pautou-se pela instauração de processos disciplinares de que decorriam ações disciplinares e disciplinadoras contra os professores e professoras das escolas públicas primárias. Quer-se dizer, o Governo contava com uma série de regulamentos que prescreviam práticas de inspeção e códigos disciplinares de ordem moral e/ou pedagógica, ainda que algumas das estratégias não passassem de meras tentativas. Desse modo, a discussão aqui apresentada é uma contribuição ao campo da história da profissão docente, especialmente uma contribuição à história da profissão docente em Minas Gerais, campo de pesquisa que precisa ser adensado com novas investigações.

Nessa perspectiva, o presente artigo se inicia com a apresentação de algumas características que regiam a organização da escola primária pública, bem como a carreira docente, especialmente quanto à admissão e a desempenhos previstos na legislação. Aborda sobre o Conselho Diretor, que ficava responsável por avaliar a conduta docente, e, especialmente, discute sobre a instauração e as consequências resultantes de 23 processos disciplinares abertos contra professores e professoras no período de 1869 a 1890.

\section{CONSIDERAC̣ÕES SOBRE A ORGANIZAC̣ÃO DA ESCOLA PRIMÁRIA PÚBLICA E A CARREIRA DOCENTE}

Até meados do século XIX, o mestre-escola ${ }^{1}$ era uma pessoa da comunidade, geralmente indicado pelos pais e, posteriormente, legitimado pelo Governo da Província. Segundo Arroyo (1985, p. 19), quando os pais das crianças indicavam os mestres, levavam em consideração certas qualidades e a experiência no ofício de ensinar as primeiras letras que dominavam. Entretanto, no decorrer da segunda metade do século, a legislação impôs novos critérios ao processo de admissão de professores(as). Eles e elas deveriam passar por um processo de avaliação - um concurso - e de formação específica - a escola normal. Foi quando o Poder Público passou a evidenciar a necessidade de existir um momento em que professores e professoras demonstrassem suas habilidades para lecionar. ${ }^{1}$ Sobretudo, foi com o advento da República que o Governo Mineiro passou a assumir, de fato, o processo de contratação dos professores(as) e a instituir os critérios de formação inerente ao trabalho docente, um plano de carreira e remuneração em conformidade com o 
zoneamento, nível escolar, número de alunos(as), tempo e tipo de formação dos professores e professoras (Arroyo, 1985; Veiga, 1992).

A instituição de um exame ou concurso para admissão na carreira do magistério já havia sido prescrita desde a Lei n. 13, de 1835, todavia passa a ser intensificada ao longo da segunda metade do século XX, o que demonstra uma antiga preocupação, por parte do governo mineiro, em regulamentar a carreira docente ${ }^{2}$. Segundo a legislação, o exame deveria ser realizado perante dois delegados examinadores, nos dias santos de Natal, Páscoa ou do Espírito Santo, pois, nesse período, os povoados costumavam se reunir. As matérias eram definidas a priori, escritas em cédulas e o assunto, sorteado no momento do exame. Entretanto, como sugerem os relatórios da Inspetoria da Instrução Pública, as nomeações eram realizadas mediante despacho e, em certas ocasiões, a fidedignidade dos resultados dos concursos era alvo de questionamento.

Embora dando prioridade aos cidadãos brasileiros, geralmente a legislação da instrução pública mineira assinalava que os estrangeiros poderiam ser professores, desde que pronunciassem bem a língua nacional. Quanto à idade, geralmente a carreira docente poderia ser iniciada com a idade de 18 anos. Entretanto, a exigência com relação à idade do(a) professor(a) levava a considerar outras variáveis, principalmente sexo e estado civil do(a) docente.

Eis algumas diferenciações identificadas na legislação analisada:

Quem já tem a idade de 21 anos completos e não mais de 50, ou a de 18 anos, se propuserem obter provimento no emprego de Adjunto nas escolas normais, ou de substituto permanente nas primárias do $2^{\circ}$ grau ou nas aulas secundárias. (...) Terem, as solteiras a idade de 20 anos, e as casadas a de 18, ou que não tem mais de 45. (Minas Gerais, Regulamento n. 44, 1859, artigos 70-1, p. 31, grifos nossos)

As professoras deveriam exibir, ademais, “(...) se forem casadas, certidão de seu casamento; se viúvas, a de óbito de seu marido (...)"; se viverem separadas deste, de sentença que julgou a separação, para ser avaliado o motivo que a originou. "As solteiras só poderiam exercer o magistério público, sendo maiores de 25 anos", salvo se viverem em companhia de seus pais e destes exibirem as competentes provas de moralidade e, neste caso, serviria a moralidade legal (Minas Gerais, Regulamento n. 56, 1867, art. 42, p. 9). 
Em linhas gerais, a legislação do período em questão estabelecia os meios de comprovar as qualidades exigidas aos professores e professoras. A legislação, que entrou em vigor em 1859, estabeleceu os seguintes critérios para a admissão no magistério:

- Certidão ou justificação processada no foro competente.

- Atestados (que sempre se entenderam jurados) das autoridades civis e eclesiásticas do Termo em que tiverem residido nos últimos 4 anos.

- Atestado dos juízes de Direito e municipais da Comarca ou Termo aos quais em algum tempo hajam residido.

- Atestado do juiz Municipal do Termo em que tenham residido nos últimos 4 anos.

- Folha corrida.

(Minas Gerais, Regulamento n. 44, 1859, art. 72, p. 32)

Diante da informalidade das relações entre o corpo docente e a instância pública identificadas no início do século XIX, cada vez mais o(a) professor(a) foi elevado ao estatuto de profissional do magistério público ${ }^{3}$. Dessa forma, incrementaram-se as exigências de uma formação especializada, de princípios éticos e hierárquicos e, sobretudo, de princípios que regiam uma carreira docente. Ela, a carreira docente, tendia a realizar o enquadramento do professor/a como efetivo, interino ou provisório, substituto ou de provimento vitalício. Além dessa categorização para todo o corpo docente, era também levada em consideração a localização da cadeira - se alocada em zona rural ou urbana.

Segundo especificação do Decreto n. 1348 de 1900, o(a) professor(a) era considerado efetivo quando ele/a fizesse parte do grupo de “(...) professores definitivamente nomeados, seja por possuírem o diploma de normalista, seja por terem provado suas habilitações em concurso." (art. 57, p. 37). Eram muitas as vantagens do corpo docente efetivo. Só poderiam ser demitidos se cometessem alguma infração prevista na legislação e mediante instauração de processo da Administração da Província. Além disso, caso a escola fosse suspensa, eles e elas continuariam a receber o salário até a escola ser restabelecida.

Também nesse decreto se prescreveu que só podiam ser nomeados professores públicos efetivos os cidadãos brasileiros que provassem ter “(...) 20 anos, pelos menos, sendo homens, de 18 anos pelo menos, sendo mulheres" (Minas Gerais, Decreto n. 1348, 1900, art. 65, p. 37). Nesse sentido, em virtude da menor idade exigida às mulheres, o 
decreto confirmava algumas das prerrogativas dadas a elas no momento de admissão. Essa estratégia, de um lado, ratificava o fato de elas serem reconhecidas como mais apropriadas e, por outro, favorecia a entrada delas no magistério público primário.

Já o(a) professor(a) interino ou provisório poderia exercer o magistério por um período máximo de seis meses. A condição de substituto acontecia quando eram “(...) nomeados para servirem durante as licenças, suspensões ou outro impedimento dos professores efetivos (...)" (MINAS GERAIS, Decreto n. 1348, 1900, art. 57, p. 37). O provimento vitalício acontecia quando o(a) docente adquiria um período em efetivo exercício. No ano de 1867 , a legislação que entrou em vigor passou a exigir a comprovação de cinco anos (Minas Gerais, Regulamento n. 56, art. 48, p. 10) e, em 1891, o período foi estendido para dez anos (Minas Gerais, Decreto n. 516, 1891, art. 38, p. 276).

Também estava prescrita, em alguns textos legais, a permissão da licença para afastamento do exercício docente. Sobre disso, entre vários motivos, a concessão de licença era dada para tratamento de negócios estranhos ao magistério, de saúde, por interesse particular ou ainda para a realização do curso normal. Os professores e professoras poderiam deixar a escola, desde que encarregassem outros de substituí-los e com a aprovação dos delegados da instrução pública.

A partir da instalação e da expansão das escolas normais, o governo mineiro passou a discriminar o(a) docente e a remunerá-lo(a), sobretudo a partir de sua formação. Dessa forma, passaram a ser reconhecidos(as) como efetivos os(as) normalistas ou os(as) que obtiveram suas cadeiras mediante concurso; e os(as) demais, como substitutos(as). Para aqueles e aquelas que se interessavam em realizar o curso normal, o Governo Mineiro estabeleceu uma prerrogativa de concessão de licença, conforme presente na Lei n. 77 de 1893.

Quanto aos deveres prescritos aos professores e professoras, estes geralmente relacionavam-se com o ideário de trabalho que vigorava em determinado momento e em conformidade com o cargo que o(a) docente ocupava. Geralmente, o teor do artigo que se referia aos deveres aparecia do seguinte modo:

I- Comparecer nas aulas e dar as lições nos dias e horas marcados e, no caso de impedimento, participá-lo ao diretor com a necessária antecedência; II- cumprir o programa de ensino, o qual deverá ser limitado a doutrina 
exclusivamente útil, sã e substancial, evitando quanto possível ostentação aparatosa de conhecimentos;

III- seguir na exposição o método que forma mais conducente à perfeita compreensão da matéria, usando sempre de linguagem ao alcance dos alunos e que esteja em relação com o grau de adiantamento destes;

IV- começar e concluir o ensino da cadeira a seu cargo por uma série de lições tendentes a ligar o assunto das ciências anteriores ao das subseqüentes;

$\mathrm{V}$ - interrogar ou chamar à lição os alunos, quando o julgarem conveniente, afim de ajuizarem do seu aproveitamento;

VI- marcar, com 48 horas de antecedência pelo menos, a matéria das sabatinas escritas, habilitando os alunos para este gênero de provas;

VII- observar as instruções e recomendações do diretor no tocante às polícia interna das aulas, e auxiliá-lo na manutenção da disciplina interna da escola; VIII- dar ao diretor, em informação escrita e trimensal, as notas do procedimento e aproveitamento dos alunos;

IX- comparecer aos exames nos dias e horas determinados, funcionando neles como presidente ou como argüentes conforme lhes competir;

$\mathrm{X}$ - comparecer às sessões da congregação.

O regulamento ampliará esses deveres como for conveniente.

(Minas Gerais, Lei n. 41, 1892, art. 229, p. 76)

\section{O CONSELHO DIRETOR E A ABERTURA DE UM PROCESSO DISCIPLINAR}

Uma das estratégias utilizadas para uniformizar e fazer cumprir o ideal de trabalho docente para a Instrução Pública na legislação em vigor foi a instauração de processos disciplinares. Mediante um conjunto de prescrições, os processos representavam uma ação disciplinar e disciplinadora do professor, pois visavam a garantir a moral e a ordem da Instrução Pública. Nesse sentido, sob a ótica do Governo da Província/ Estado e de seus representantes, o processo disciplinar representava uma prática de policiamento. Em direção contrária, para os professores e professoras significava estratégia de perseguição. Nesse caso, no mínimo, eram duas as versões.

Era o Conselho Diretor que deveria instaurar os processos disciplinares. E, segundo o Regulamento n. 62 de 1872, tal instância deveria ser composta:

Do inspetor geral, seu presidente.

Do diretor do liceu.

De um professor do Liceu, que seja também da escola normal.

De um professor primário público ou particular distinto no magistério. 
De dois cidadãos ilustrados, que não pertençam ao magistério.

(Minas Gerais, Regulamento n. 62, 1872, art. $7^{\circ}$, p. 4-5)

Ao Conselho caberia averiguar e emitir pareceres a respeito da conduta do corpo docente. Além de julgar as infrações disciplinares dos professores e professoras e auxiliar o Inspetor Geral, o Conselho Diretor tinha por função "o exame dos melhores métodos e sistemas práticos de ensino", "a revisão e aprovação dos compêndios e livros para as aulas", "a criação de novas cadeiras" e "o sistema e matérias dos exames" (Minas Gerais, Regulamento n. 62, de 1872, art. 10, p. 5).

A abertura de um processo disciplinar acontecia a partir de qualquer queixa ou denúncia - de ordem moral, econômica e/ou pedagógica - realizada por parte da Inspetoria de Instrução Pública ou até por qualquer cidadão. Qualquer manifesto público poderia desencadear a abertura de um processo. Eis um exemplo:

S. João Batista, 28 de dezembro de 1878 - (do correspondente).

A escola de instrução primária do sexo masculino da freguesia de Santa Maria, regida por H. L. S., acha-se abandonada. Há longos meses não leciona esse professor que constantemente emprega-se por fora em mascateações de fazendas, sem que esteja competentemente licenciado, deixando a cadeira entregue aos cuidados de sua mãe D. Bernadina. Assim como este, procedem outros professores e, entretanto, nenhuma providência é tomada por aqueles à quem foi confiada a direção do ensino público. Temos certeza de que clamamos no deserto, levando à luz da publicidade os atos praticados pelos agentes subalternos da instrução pública; não obstante, prosseguiremos no cumprimento de nosso dever, denunciando os abusos e imoralidades dos agentes do atual governo (Jornal A provincia de Minas, 24/01/1879, PP 1/42, Caixa 15, Documento 10).

Nesse caso anterior, encontram-se denúncias da ordem de infrequência do professor e consequente transferência da sua responsabilidade docente, bem como o exercício de outra atividade concomitante ao magistério. Todavia, outras cartas com denúncias de comportamentos vistos como "imorais" ao cargo docente eram dirigidas à Inspetoria Geral da Instrução Pública e chegavam também a ser publicadas em jornais. Particularmente, a denúncia apresentada a seguir se vale de argumentos que abarcam praticamente comportamentos de ordem privada doméstica. Foram essas as palavras do denunciante: 
Ao Sr. Inspetor Geral da Instrução Pública da província de Minas.

É com o maior pesar que eu venho hoje denunciar o professor público da infeliz Freguesia de Perdões de Lavras, o Sr. H. P. C. B. Nunca pretendi acusar alguém, mais, trouxeram-me aqui a voz de minha consciência e o grito da moralidade. Senhor! É esse catão caricato um tipo depravado, analfabeto, devasso, alcoviteiro, mau pai de família, mau cidadão e pederasta sem igual, quer por honra da humanidade antes não existisse. Este mísero verme, calígula devassíssimo, tem um serralho de meninos e escravos, e são patentes esses fatos à sua esposa, vítima de tantos sofrimentos!... Apresentou-se como procurador da festa do Divino E. Santo, e consumiu todas as esmolas. Há pouco pretendeu engulir $200 \$ 000$ do honrado cidadão Godofredo Alves de Castro, e não realizou a engulição por se desconfiar de suas bravuras, tomando-se as precisas precauções. Senhor! É impossível numerar todos os horrorosos fatos praticados por este Nero estúpido! Enfim a depravação desse analfabeto, chegou a tal ponto que sua mulher e seu filho o quiseram assassinar, o que não teve efeito por se descobrir a pretensão. Esperamos, pois, sérias providências do Sr. Inspetor da Instrução Pública desta Província de Minas Gerais. Continuaremos. Os perdoenses. Perdões, 8 de novembro de 1884. (Gazeta dos Passos, 28/12/1884, PP 1/42, Caixa 31, Documento 3).

Ou, ainda, a denúncia se dava mediante correspondência estabelecida entre inspetores paroquiais ${ }^{4}$ e Inspetoria Geral da Instrução Pública ou dela com a Administração da Província. Desse modo, ficavam os membros da comissão do Conselho Diretor responsáveis por averiguar a procedência da acusação e emitir o parecer sobre o delito do(a) professor(a). Para tanto, havia na legislação alguns artigos que prescreviam as faltas e as respectivas punições que deveriam ser atribuídas ao corpo docente. Sobre isso, toma-se como exemplo de uma prescrição criteriosa o que estava presente no Regulamento n. 44 do ano de 1859, uma norma extensa intitulada de punição das faltas ou delitos dos preceptores públicos. ${ }^{5}$

Mediante o exposto sobre o processo de instauração de processos disciplinares, tomam-se como objeto de análise para este artigo especificamente 23 processos que foram identificados no Arquivo Público Mineiro. O Quadro 1 permite uma visualização geral dos dados coletados no que se refere aos motivos que levaram à instauração de processos disciplinares e os respectivos pareceres que foram emitidos pelo Conselho Diretor. Todavia, para a composição desse quadro, foram considerados, quanto aos motivos, a linguagem presente nas fontes pesquisadas. 
Quadro 1: Motivos de denúncia e parecer final dos processos disciplinares de professores e professoras da Província/Estado de Minas Gerais (1869-1890)

\begin{tabular}{|c|c|c|c|c|}
\hline Motivo(s) & Sexo & Ano & Parecer Final & Fonte consultada \\
\hline $\begin{array}{l}\text { Imoralidade, incapacidade profissional e ocupar- } \\
\text { se da venda unida à escola }\end{array}$ & $\mathrm{M}$ & 1869 & $\begin{array}{c}\text { A escola é } \\
\text { fechada e perda } \\
\text { da cadeira }\end{array}$ & $\begin{array}{l}\text { PP } 1 / 42 \text { cx. } 15 \\
\text { doc. } 10\end{array}$ \\
\hline $\begin{array}{c}\text { Perseguição de alguém que é desafeto, desprovi- } \\
\text { do de conhecimentos básicos } \\
\text { para o magistério }\end{array}$ & $\mathrm{M}$ & 1873 & - & $\begin{array}{l}\text { PP } 1 / 42 \text { cx.18 } \\
\text { doc. } 1\end{array}$ \\
\hline Professor toma parte em questões políticas & M & 1875 & $\begin{array}{l}\text { Concessão de } \\
\text { remoção }\end{array}$ & $\begin{array}{c}\text { PP } 1 / 42 \text { cx.21 doc. } \\
21\end{array}$ \\
\hline Comércio & $\mathrm{M}$ & 1877 & Absolvido & IP 67 \\
\hline Acusação de abandono de cadeira & $\mathrm{F}$ & 1881 & $\begin{array}{l}\text { Professora é } \\
\text { reintegrada } \\
\text { em } 1887\end{array}$ & $\begin{array}{c}\text { PP } 1 / 42 \text { cx.23 doc. } \\
30\end{array}$ \\
\hline $\begin{array}{l}\text { Depravado, analfabeto, devasso, alcoviteiro, } \\
\text { mau pai de família }\end{array}$ & $\mathrm{M}$ & 1884 & $\begin{array}{c}\text { Pede novos } \\
\text { esclarecimentos }\end{array}$ & $\begin{array}{l}\text { PP } 1 / 42 \text { cx.31 doc. } \\
31\end{array}$ \\
\hline $\begin{array}{c}\text { Proceder mal, embriaguez, dar tiros nas portas } \\
\text { dos cidadãos, deixar de dar aula durante oito } \\
\text { dias, jogatinas e passeatas }\end{array}$ & $\mathrm{M}$ & 1885 & $\begin{array}{l}\text { Absolvido do } \\
\text { processo }\end{array}$ & $\begin{array}{l}\text { PP } 1 / 42 \text { cx.28 doc. } \\
01\end{array}$ \\
\hline
\end{tabular}

\begin{tabular}{ccccc}
\hline $\begin{array}{c}\text { Má conduta moral, ficar dias sem ministrar aula } \\
\text { e embriaguez }\end{array}$ & M & 1886 & - & $\begin{array}{c}\text { PP 1/42 cx.33 doc. } \\
04\end{array}$ \\
\hline $\begin{array}{c}\text { Ao inspetor nega-se a avisar os } \\
\text { certificados da escola }\end{array}$ & F & 1886 & Absolvida & PP 1/42 cx.37 doc. \\
12
\end{tabular}

FONTE: Arquivo Público Mineiro

Foram localizados 23 processos, sendo 20 contra professores e três contra professoras. Nesse caso, pode-se considerar como uma forte 
hipótese a possibilidade de maior ocorrência de denúncias e, consequentemente, processos disciplinares dirigidos aos professores do sexo masculino. Isso pode ser explicado a partir de algumas perspectivas. A primeira diz respeito ao fato de o número de homens professores ser maior que o de mulheres. ${ }^{6}$ A segunda refere-se ao fato de as mulheres já estarem acostumadas a viver submetidas à vigilância desde crianças e, por isso, coibidas em relação ao respeito a regras sociais. Por último, o desejo de manter-se no magistério, em decorrência de ele representar uma oportunidade de exercer atividade fora do espaço doméstico e remuneração, o que poderia contribuir para que as mulheres tendessem a aceitar mais o que foi imposto pelo Governo.

Quanto aos motivos, os processos foram instaurados mediante queixas e denúncias oriundas das mais variadas razões, quais sejam: de ordem econômica, moral e/ou pedagógica. Assim, desde o cumprimento inadequado do trabalho docente em seu sentido estrito até a condição de amásio, de embriaguez e de ser mau pai e chefe de família foram alguns dos motivos de manifestos públicos contrários ao que seria considerado como docente apto ao cargo do magistério primário. Em alguns casos, os processos disciplinares eram desencadeados porque os professores e professoras abandonavam a docência por diferentes motivos, todavia pode-se inferir que a abertura do processo também poderia gerar o mesmo fato.

Os 23 processos disciplinares sugerem que os motivos, em sua maioria, foram mais de ordem econômica e/ou moral do que precisamente de ordem pedagógica. Somente em três processos, em dois deles juntamente com demais motivos, aparecem as denúncias quanto à "incapacidade profissional", a ser "desprovido de conhecimentos básicos para o magistério" e ao fato de que uma professora "nega-se a avisar os certificados da escola".

Motivos infundados ou não - isso não está em questão -, quanto ao parecer final, em dez deles os docentes foram absolvidos, em sete casos perderam a cadeira, quatro processos tiveram outros desfechos e em dois casos não constava o parecer final. 


\section{O PROCESSO DE AVERIGUAĈ̣̃O DA DENÚNCIA}

Com base nas infrações previstas na legislação e tendo em vista averiguar a procedência da denúncia, os 23 processos disciplinares analisados demonstram que se firmou um intenso diálogo entre os diferentes representantes do governo - Conselho Diretor e inspetores -, membros da comunidade e acusado(a). Com o intuito de averiguar a veracidade das acusações, da Presidência do Governo Mineiro foi endereçada ao Diretor Geral da Instrução Pública uma correspondência solicitando a informação de dois professores primários, com os seguintes dizeres:

Palácio da Presidência da Província de Minas Gerais. Ouro Preto, 23 de Setembro de 1867. Cumpre que V.Sa. me remeta as informações oficiais sobre o professor de Sant'Anna do Paraopeba, Antônio José da Silva, já exigidas, informando se é ele vitalício, e matéria do Título e a data de sua nomeação, e bem assim se o professor Jerônimo José Barbalho é vitalício, está avulso, e no caso afirmativo desde quando, e porque motivo. Deus guarde a V. Sa. José Maria Correa de Sá e Benevides Sr. Dr. Diretor Geral da Instrução Pública. (PP 1/42, Caixa 15, Documento 10).

Em resposta à correspondência enviada, o Diretor Geral da Província de Minas Gerais envia, em 29 de setembro de 1867, as seguintes informações sobre os professores:

Cumprindo a ordem constante do ofício da V.Exa. datado de 25 do corrente, tenho a honra de passar às mãos de V.Exa., por cópia a informação que prestei sobre o professor primário da Sant'Anna do Paraopeba em 16 de Agosto próximo passado e a que me foi prestada pelo Delegado desta Diretoria naquele distrito, não me tendo ainda respondido o da cidade do Bonfim.

Devo mais informar a V.Exa. que este professor não se chama Antônio José da Silva, mas Antônino José da Silva; e que foi nomeado por portaria de 17 e título de 20 de julho de 1864, não sendo portanto vitalício e nem podendo sêlo enquanto não se habilitar na forma do Regulamento 56, artigo 48.

Quanto ao professor Jeronymo José Barbalho cumpre informar que não era ainda vitalício, quando the foi cassado o título e suprimida a cadeira pela portaria de 16 de fevereiro de 1865, que junto por cópia, pelas razões constantes da mesma portaria e da informação também junta por cópia, da seção da secretaria do governo.

Deus guarde a V.Exa. Ilmo. Exmo. Sr. Dr. José Maria Corrêa de Sá e 
Benevides. M. D. Presidente da Província. Firmino Antônio de Souza. (PP 1/42, Caixa 15, Documento 10).

Se não as próprias correspondências dos professores, foram algumas referências realizadas por terceiros que permitiram ao professor ou professora justificar-se diante da acusação. Sobre isso, eis aqui uma defesa de um professor:

$A$ isto responde o professor: $1^{\circ}$ Que com as escritas de seus alunos, e com o resultado dos exames, desde 1859 até 1863, ele prova que não é desleixado, mas antes solícito no cumprimento de seus deveres. $=2^{\circ}$ Que o mapa do artigo $3^{\circ}$ ele prova que no ano passado saíram de sua aula alguns discípulos sabendo bem ler, escrever, contar e a doutrina. $=3^{\circ}$ Que é inexato que os alunos matriculados na ocasião dos exames fossem todos de data de 1861 porque desse ano só existiam 13 mas que 11 se tinham matriculado desde Janeiro de 1863 até Janeiro de 1864. = 4 Que não pode o professor vencer impossíveis e que sendo esses 13 alunos de curta inteligência não podiam vencer o trabalho com a facilidade, mas que isso não podia servir de motivo para inferir sabe muito bem que de sua aula saíram no próximo passado ano muitos alunos prontos, mas que prevalecesse do exame em que não compareceram para referir-se a alunos que haviam dois meses tinham entrado para a escola, ocultando mesmo aquilo que consta da ata do exame a que presidio, da qual não só consta que foram julgados prontos dois como muito adiantados 6, dos 24 presentes. $=6^{\circ}$ Que é verdade que tem um pequeno negócio; mas que só trata dele depois das horas letivas, e que isto é público. $=7^{\circ}$ Que sua casa tem todas as acomodações para a aula, e que se o número de aluno crescer, ele a aumentará. $=8^{\circ}$ Finalmente que a orgia de que fala o Inspetor consistiu em cantar umas modas em casa de um cidadão idoso e honrado por ocasião do casamento de sua filha. = Em conclusão, averba o Inspetor de parcial e seu inimigo figadal, tanto que remetendo o ofício do Inspetor Municipal enviado pelo Governo guardou o seu, dando causa a que o reclamasse como provara com os ofícios juntos que lhe foram dirigidos. = Para provar suas asserções juntou o documento $\mathrm{n}^{\mathrm{o}} 1^{\mathrm{o}}$ (escritas dos seus alunos e declarações de três indivíduos, que lhe são favoráveis.) $\mathrm{O}$ de $\mathrm{n}^{\mathrm{o}} 2$ consistindo em cópias de atas de exames praticados em sua aula. = A seção junta os mapas gerais desta escola relativos aos anos atrasado e passado e notou duas contradições quanto aos alunos. = Simão Gonçalves Campos e Jacinto Ferreira de Jesus = Pelo mapa do ano passado vê-se que esta aula não é freqüentada pelo $\mathrm{n}^{\circ}$ legal, e a lei manda suprimi-la. $=13$ de Fevereiro de 1865. = Assis Martins.

(PP 1/42, Caixa 15, Documento 10, grifos nossos). 
Quando os professores e professoras endereçavam suas defesas à administração da Província/Estado, adjetivavam as denúncias de perseguições e alguns deles e delas aproveitavam para solicitar sua remoção para outra cidade. Em algumas circunstâncias acontecia de o próprio Conselho Diretor sugerir tal condução. Também as perseguições assumiam o caráter de ser político-partidárias. Uma situação de perseguição política ocorrida em uma das cidades do norte da província é descrita no excerto abaixo:

A transferência do professor Juca Teixeira de Senhor do Bonfim para Nossa Senhora Santana de Contendas não podia ser e não foi um ato de sua livre e espontânea vontade. Homem pobre, família numerosa, mudar-se de Bocaiúva, onde estava radicado, entre parentes e amigos, próximo de Montes Claros, onde residiam seus irmãos, para lugar mais distante, meio estranho, mais afastado dos seus, era, sob todos os pontos de vista, um desastre e não podia ser um ato voluntário. Aí estava claro o dedo da política, uma perseguição dos adversários. Não podendo exonerar um funcionário vitalício por concurso, fazia o máximo: removia-o. (TEIXEIRA, 1975, p. 17-18)

É pertinente considerar que, naquele momento, a sociedade estava passando por radical revisão dos princípios políticos, principalmente o movimento liberal em oposição às ordens imperial e escravocrata. Dessa forma, as desavenças políticas podem ter sido traduzidas nos momentos de denúncia como transgressões morais, transgressão ao instituído pelo Império. Como bem destaca Mattos (1999), naquele momento, o Governo de Estado tinha em vista controlar o mundo da rua não somente em decorrência das influências dos princípios higienizadores, mas também do número de movimentos que se insurgiam em defesa do projeto liberal.

Além do pároco, o delegado de polícia da respectiva cidade do(a) candidato(a) à cadeira também fazia parte do rol de pessoas que poderiam confirmar ou não a idoneidade do(a) professor(a). No caso do delegado, deveria declarar se o(a) candidato(a) já estivera envolvido(a) em roubo, furto, briga, embriaguez e outros. Entre os atestados que fazem parte do acervo do Arquivo Público Mineiro, apresenta-se, a seguir, um exemplo de correspondência encaminhada pelo delegado de Polícia à Administração da Província Mineira, desaconselhando a remoção e a permanência de um professor na Instrução Pública. Nas palavras do delegado: 


\section{Confidencial}

Ilmo e Exmo Sr.

Tendo sido removido a bem do serviço público em dias de maio do ano passado, o professor de primeiras letras dessa cidade J. B. M. para igual cadeira na cidade de Ubá, procurou o mesmo professor obter a reintegração agenciando para isso um abaixo assinado de algumas pessoas, mas o meu antecessor, Capitão Mor Carlos Augusto Ribeiro Campos fez chegar ao conhecimento do Governo provincial por intermédio do Dr. Chefe de Polícia a inconveniência de tal reintegração pelo motivo de ter o mesmo professor tomado parte e ser um dos autores dos acontecimentos que tem perturbado a paz dessa cidade a ano e tanto, obrigando por isso a conservação nela de um delegado militar de polícia, em vista do que não obteve o dito professor a reintegração. Agora, porém, acha-se ele nesta cidade procurando outra vez ser removido para a cadeira da qual tal justamente deixou de ser professor e por isso julgo do meu dever como Delegado de Polícia deste termo ponderar a V. Excia. a bem da paz e tranqüilidade dessa cidade a inconveniência de tal remoção pois com a ausência do mencionado professor e alguns de seus comparsas tem melhorado o estado da cidade, por isso rogo a V. Excia. em vista do que tenho a honra de expor de levar tudo ao conhecimento do Exmo. Presidente da Província que na repartição da Instrução Pública e Secretaria de Polícia achará documentos que mostram o procedimento irregular deste professor nesta cidade. Assina o Delegado de Polícia. 25/01/1877.

(IP 1/7, Caixa 01, Documento 31).

A legislação era infringida não somente pelos professores e professoras, mas também pelos inspetores. Assim sendo, pode-se questionar a fidedignidade das cartas que inspetores da Instrução Pública e demais pessoas da comunidade encaminhavam para o Conselho Diretor. Elas divergiam com relação às infrações cometidas pelos professores e professoras, bem como quanto à sua idoneidade. Vale ressaltar que foram muitas as correspondências dos(as) professores(as) endereçadas ao Governo Mineiro acusando os inspetores da Instrução Pública de perseguição.

Baseando-se nesses fragmentos de processos disciplinares, podese discutir a existência de tentativas de esquadrinhamento da vida privada do corpo docente. O Governo de Estado, em nome de um projeto de sociedade, de escola e de professor, procurava regular os mundos da casa e da rua, como descrito por Mattos (1999) ${ }^{8}$.

No mundo da rua estavam aqueles e aquelas que eram vistos como vadios e desordeiros e entregues à indolência e à preguiça. Geralmente 
eram pessoas que traziam intranquilidade para o sistema vigente, uma vez que apareciam nas rebeliões ou, ainda, manifestavam-se em defesa dos escravos e da formação de quilombos. Também estavam os loucos, os embriagados e portadores de anomalias, pessoas estas que manifestavam comportamentos desregrados. Aliada à Medicina dos higienistas, o governo passou a esquadrinhar os comportamentos da família, argumentando principalmente que, em relação às crianças, os pais as educavam mal em decorrência da ignorância (MACHADO et al., 1978; COSTA, 1979).

Todavia, nesse contexto, sucedia não somente a negação de que os pais eram os melhores para educar os filhos, mas também de que a instrução deveria acontecer distante e separada da casa do professor ou da professora. ${ }^{9}$ Contudo, outras estratégias contrariavam tal distanciamento. Sobremaneira, era o atestado de idoneidade, da ordem da vida privada e doméstica que ratificava a condição de o(a) professor(a) ser ou não exemplo para as crianças ou, em outras palavras, se ele ou ela era de vida regular e próprio(a) para o ensino da mocidade. Entretanto, ressalte-se que, em algumas circunstâncias, o esquadrinhamento da vida privada não passava de mera tentativa.

\section{ESQUADRINHAMENTO DO TRABALHO DOCENTE}

Embora existissem, por parte de diferentes segmentos da sociedade, algumas denúncias relacionadas à prática pedagógica - ou seja, relacionadas ao ensino propriamente dito - dos professores e professoras, parece que o teor delas não era agravante a ponto de desencadear a abertura de processos contra os docentes. Entretanto, isso não constituía um fato isolado, ou seja, existia uma tendência de ele ser apenas mais um entre tantos e/ou estar relacionado aos demais. As questões relacionadas ao ensino eram importantes, mas talvez não fossem tanto quanto os aspectos morais ou políticos.

Eis aqui um exemplo dos argumentos apresentados:

Cópia - $6^{\mathrm{a}}$ sessão - O Inspetor Paroquial do Rio do Peixe acusou o professor de Primeiras Letras Jeronimo José Barbalho. $=1^{\circ}$ De não seguir no ensino o método designado pela lei. $=2^{\circ}$ De não cuidar do progresso de seus alunos tanto que de 24 freqüentes só dois se distinguem por causa de seu talento. $=$ $3^{\circ}$ De ocupar-se mais da venda que tem unida à escola e conservar a aula em 
uma sala estreita, onde os meninos ouvem todas as palavradas indecentes que soem aparecer nas tavernas. $=4^{\circ}$ Ser o professor, por causa de seus desregramentos, a causa de existirem mais de 30 alunos analfabetos, pois os pais preferem esse estado, a seus filhos aprenderem vícios degradantes e vergonhosos. $=5^{\circ}$ De dar aula em o pior local da povoação, que por estar em lugar baixo e sujeito as inundações, exala pútridas emanações que muito deterioram o físico dos meninos, sujeitando-os as febres intermitentes. $=6^{\circ}$ Que negou-se a mostrar-lhe a lista das falhas de Abril e maio porque elas foram repetidas e por mais de 5 dias cada vez. $=7^{\circ}$ Que apesar de ter sido castigado por embriagar-se e meter-se em orgias imorais, continua, se bem que não à luz do dia, na mesma lida do abrigo das trevas.

(PP 1/42, Caixa 15, Documento 10).

Nesse caso, mesclados com outros motivos, se encontrava o argumento de que o professor ou professora não realizava adequadamente o ensino às crianças. Portanto, faz-se necessário considerar que, ao longo da segunda metade do século XIX, se passou a desprezar o saber acumulado pelos(as) mestres(as) durante o exercício de suas práticas de instrução. Até então, o velho mestre, denominado de mestre-escola ou mestre de ofício ${ }^{10}$, exercia suas atividades fundamentadas nas atividades realizadas pelas corporações. Em oposição, através do processo de incorporação de conhecimentos específicos das ciências da educação, especificamente da Psicologia e da Pedagogia, obtidos nas escolas normais, os professores e professoras foram passando por um processo de profissionalização ${ }^{11}$ (ENGUITA, 1991; DUBAR, 1997). Em decorrência, a Província/Estado mineira impôs novos princípios para a regulamentação da instrução e para os(as) mestres(as) que pertenciam ao quadro docente público (ARROYO, 1985; GOUVEA, 2000; GOUVEA; ROSA, 2000; DURÃES, 2002). Em linhas gerais, foram a oposição entre profissão e ofício, as exigências por uma formação específica, as tentativas de construção de um saber pedagógico e, sobretudo, os critérios de admissão e de carreira que se fizeram presentes naquela época e passaram a delinear o estatuto profissional do trabalho docente.

Também o educador como imagem ideal coincidiu com o momento em que algumas virtudes, como moral, obediência, além de carinho, amor e vocação, passaram a fazer parte das qualidades necessárias ao trabalho docente. Não somente nos relatórios dos inspetores mineiros, nos discursos dos governantes e em outros diferentes segmentos sociais chegavam a ser uníssonos relatos de que o trabalho docente não poderia 
mais ser realizado por aquele(a) que não tinha gosto pelo magistério, que abandonava seus alunos e ia cuidar da sua venda ao lado da escola, que era carrancudo com os alunos e alunas e que se valia da palmatória para obter respeito. A Pedagogia sugeria que era preciso reconhecer a fraqueza das crianças e, com moderação, reclamá-las (WARDE, 1999).

\section{NEGÓCIOS ESTRANHOS AO MAGISTÉRIO}

Mesmo à revelia da legislação da Instrução Pública Mineira, o corpo docente mantinha negócios estranhos ao magistério. Essa denominação era atribuída pelo Governo Mineiro a qualquer atividade econômica que os professores e professoras exercessem diferente do trabalho docente. Nos processos de denúncia contra o corpo docente, como no caso das questões morais ou do não-cumprimento de suas funções de professor(a), também se encontram, nos processos disciplinares existentes no Arquivo Público Mineiro, declarações de pessoas de determinada comunidade alegando (ou não) que ele(a) realizava atividades estranhas ao magistério. $\mathrm{O}$ fato de o professor(a) manter um comércio unido à sua casa era razão para denúncia e consequente instauração de processo disciplinar. Quando comprovado, geralmente culminava em perda da cadeira, ou seja, demissão.

Não só a solicitação de permissão para exercer um negócio estranho ao magistério como também as denúncias de sua ocorrência foram fatos de grande incidência nas correspondências a que se teve acesso no Arquivo Público Mineiro. Além disso, nas fontes pesquisadas pôde-se observar maior tendência aos pedidos dos professores do sexo masculino do que do feminino. Geralmente eram homens que pediam permissão para abrir uma casa comercial, que eram bodegas, minifábricas de licores, venda de gêneros alimentícios, de fazendas ou de gêneros do país. Mas também havia pedidos para dar aula particular, para exercer atividade como farmacêutico, para ser escriturário comercial, entre outros. Também por Arroyo (1985, p. 120) não passou desapercebido o número desses pedidos.

Alguns professores(as) solicitavam a permissão para executar tais atividades, outros, mesmo sem ela, mantinham algum negócio estranho. Havia também aqueles que saíam ilesos do processo disciplinar e continuavam exercendo atividades paralelas ao trabalho docente. Ou 
ainda, como evidencia a correspondência seguinte, embora o professor já tivesse sido submetido ao processo disciplinar, era seu desejo continuar com uma atividade paralela ao trabalho docente.

Diz Hermenegildo José Pimenta, professor público da freguesia de Santo Antônio do Pessanha, município da cidade do Serro, que desejando ter um pequeno negócio em sua residência, administrado por terceira pessoa, em o qual o suplicante só tomará parte nas horas vagas e como não pode fazer sem licença de V.Sa. como determina o regulamento em vigor, vem perante V. Sa. solicitá-la.

(IP 1/5, Caixa 03, Documento 44).

Tem-se por hipótese que o desejo de realizar concomitan temente duas atividades de trabalho pode ter conduzido o professor ou professora a manifestar resistência entre a separação da casa e da escola. Em algumas correspondências encaminhadas pelos professores e professoras ao governo mineiro pode-se identificar tal aspecto. Aos pedidos encaminhados, a administração respondia com a seguinte frase: vide legislação em vigor. Ou seja, em linhas gerais, era “(...) absolutamente vedado ao professor qualquer encargo comercial ou industrial, permanente ou temporário (...)" (Minas Gerais, Regulamento n. 56, 1867, art. 100, p. 27).

Além de o pedido anteriormente mencionado ter sido indeferido, constava, anexada ao seu pedido de licença, uma pequena ficha onde estava registrado que ele já havia sido submetido a processo disciplinar em agosto de 1875, em virtude de ter exercido negócios estranhos ao magistério.

Com a finalidade de dar sustentação às suas solicitações e sensibilizar o poder público, nas correspondências, os professores geralmente alegavam que a realização de outra atividade econômica se fazia necessária diante do exíguo salário e de eles terem de sustentar a numerosa família. Segue um exemplo com tais alegações:

Diz Tertuliano Minito da Silva professor público de Instrução primária da Vila de Pouso Alto que tendo obtido licença do antecessor de V.Sa. para se empregar nas horas vagas em escrituração forense e comercial e não tendo mencionado no pedido de licença para requerer em juízo, também nas horas vagas, por isso vem respeitosamente pedir V.Sa. se digne conceder-lhe essa licença da qual o suplicante fará uso sem prejuízo ao ensino e ao 
cumprimento de seus deveres e obrigações, afim de que assim o suplicante possa se manter com decência, pois que além de não ser pequena a sua família, mora num lugar onde são caros os gêneros alimentícios e excessivos o aluguel das casas. Ouro Preto, 20/10/1877.

(IP 1/5, Caixa 04, Documento 38).

Entre as diferentes atividades que se expandiram, talvez seja o comércio varejista uma das que mais tenha despertado o interesse do sexo masculino. Embora seja difícil dimensionar o número de professores homens que, concomitantemente ao magistério, exerceu essa atividade ou ainda que o abandonou por esse motivo, o número de correspondências endereçadas por eles à administração, solicitando uma permissão, é, no mínimo, uma forte evidência da situação dominante na época.

Além disso, a linha férrea e a economia cafeeira concorreram para que houvesse o surgimento de novas frentes de trabalho na Província de Minas Gerais, já a partir da década de 70 de oitocentos. Para ilustrar o quadro descrito:

Diz Manoel Athanasio de Villanova, professor da escola pública de instrução primária da freguesia de João Gomes que havendo no lugar grande carestia de gêneros alimentícios por causa da fartura da estrada de ferro, não pode o suplicante passar somente com o seu tênue ordenado, vem por isso requerendo a V. Sa. a graça de conceder-lhe licença para ocupar-se de qualquer negócio estranho fora das horas de ensino diário como permite o art. 20 da portaria do exmo. Governo de 18/04/1872.

(IP $1 / 5$, Caixa 02, Documento 03).

A respeito da licença para tratamento de negócios estranhos ao magistério houve muitas controvérsias. Todavia, em alguns momentos, o Governo Mineiro, apoiando-se na legislação, colocava-se radicalmente contrário a tais atividades; em outros, abria algumas concessões. Se a administração da província confirmasse que o professor ou professora estava realizando alguma atividade diferente do magistério, no período em que ela não se encontrava em vigor, geralmente acontecia a demissão do(a) professor(a), visto que o Governo Mineiro exigia a exclusividade do corpo docente.

Da legislação pesquisada referente ao período de 1860 a 1900, somente em um curto período o Governo de Minas fez concessão para que os professores e professoras pudessem exercer um negócio estranho ao magistério. Até o Regulamento n. 100, de 1883, a licença para tratamento 
de negócios era vetada aos professores e professoras. A partir desse período, passou-se a conceder um mês, com direito a prorrogação de mais um mês. Posteriormente, em 1900, retornou a proibição do exercício de atividades diferentes do magistério.

Dessa forma, foi possível verificar que, paulatinamente, o estatuto do magistério primário passava a requerer maior exclusividade do(a) professor(a). A legislação do governo mineiro e os princípios higienizadores e pedagógicos passaram a exigir dele(a) mais horas em sala de aula, tempo para preparar as atividades de ensino, dedicação aos alunos, estudo e outras atividades relativas ao trabalho docente. Tudo isso requeria do professor e professora não somente as suas horas em sala de aula, mas também muitas horas além delas.

\section{EXCLUSÃO E/OU ABANDONO DO MAGISTÉRIO?}

O último aspecto que se passa a considerar neste artigo diz respeito ao argumento de que o processo disciplinar foi uma das estratégias que favoreceu a saída - por exclusão e/ou abandono - de professoras e, sobretudo, de professores do magistério. A saída deles pode ser interpretada como abandono se se considerar que os homens foram paulatinamente fazendo opção por atividade diferente do magistério (ENGUITA, 1991; DEMARTINI; ANTUNES, 1993; APPLE, 1995). $\mathrm{Ou}$, ainda, aconteceu a exclusão daqueles que assumiam certos comportamentos masculinos indesejados e não-previstos no novo projeto de escola primária. Com efeito, a evasão dos homens dos cursos normais, como também das escolas primárias, deve ser analisada em duas direções. Em direção à análise da exclusão quer-se argumentar que a qualificação docente, requerida pelo Governo Mineiro, tinha em vista um processo de avaliação e seleção dos professores e professoras. Não somente os critérios considerados para a avaliação e a seleção se afastavam dos atributos masculinos como ocorria também, por parte do Governo, a exigência de formação específica para o magistério e dedicação exclusiva. Diante do tipo de trabalho que os homens estavam acostumados a realizar até então, a nova organização escolar os forçava a deixá-la.

O trecho a seguir, por exemplo, apresenta uma justificativa de saída de um homem para o exercício de outras atividades: 
O juiz de direito da comarca do Rio Lambari informa ao Inspetor Geral sobre o abandono da Cadeira da freguesia do Japão. Afirma ele que o professor público F.R. abandonou a escola para exercer a profissão de encomendeiro e por aqui tem aparecido várias vezes tratando de negócios particulares de terceiros. 18/06/1887.

(IP 1/7, Caixa 01, Documento 38).

Nesse sentido, estar na sala de aula representava para alguns um arranjo passageiro porque estavam à espera de ocupação em outros postos do serviço público, que se aproximavam mais das qualidades masculinas no que diz respeito às habilidades e à compatível remuneração. Como sugerem Demartini e Antunes (1993), o magistério primário tendia a ser representado, na transição entre o Império e a República, como profissão feminina e carreira masculina.

Mas, afinal, para onde os homens iam de fato? O novo trabalho era mais lucrativo? As fontes consultadas não evidenciaram dados que permitissem responder categoricamente a essas perguntas. Somente a análise da trajetória de vida e profissional dos homens poderia sustentar tal argumento. Todavia, até onde as fontes permitem afirmar, pode-se dizer que a remuneração era exígua se comparada com alguns postos de trabalho que surgiram ou que se expandiram naquela época (Cf. DURÃES, 2007).

Mas, ao lado da diminuição no número de homens no magistério, de acordo com as fontes consultadas, também algumas mulheres abandonaram-no. Entretanto, é pertinente salientar que, entre todos os casos de denúncia de abandono ou mesmo de negócios estranhos ao magistério, com relação às mulheres professoras, houve pequena incidência, se comparados com o número masculino.

Analisando alguns poucos casos de abandono relacionados às mulheres professoras, um deles se referia a envolvimento criminal. Infelizmente, a fonte consultada não especificava qual era o tipo de envolvimento da professora no crime. Tratava-se de um ofício encaminhado pela Administração da Província, no ano de 1877, ao Inspetor Público e ele, por sua vez, informava que o abandono do cargo acontecera porque ela estava foragida da polícia (cf. IP 67). Com efeito, tal fato ocorrera, embora indistintamente, para homens ou para mulheres, fosse exigida, pela legislação, a idoneidade moral e religiosa do corpo docente. Sendo os professores e professoras reconhecidos como exemplo para as crianças, 
eles e elas não deveriam macular os comportamentos que a sociedade esperava que tivessem.

Ao Sr. Francisco Pinheiro Costa, Inspetor Escolar ambulante de Diamantina.

Tendo sido acusada a professora da cadeira de Bragres, município do Curvelo, Dona Maria A. C. de viver separada de seu marido e desonestamente recomendo-vos para por aí recolher informações que a tempo transmitireis a esta secretaria, sem o fato de que é acusada aquela professora. Igual diligência recomendo-vos que façais em relação ao professor da cadeira de Capim Branco, do mesmo município, cidadão G.A.C. que é acusado de haver deflorado uma menor de quatorze, sua discípula. 28/11/1893.

(SI 655).

Outra acusação de abandono feminino do cargo refere-se a uma professora que solicitara uma licença de três meses para tratar da sua saúde e, segundo ela, os documentos que comprovavam o seu estado de saúde não haviam sido encaminhados pelo Delegado de Instrução. Nas palavras da professora, o Delegado era um homem "roceiro quase analfabeto e inimigo figadal do seu marido" (PP 1/42, Caixa 23, Documento 30).

Enfim, o pequeno número de denúncias de casos de abandono encontrado referente às mulheres professoras é forte evidência do significado que o magistério tinha para elas. O magistério primário significou uma possibilidade de profissionalização e de remuneração. Além disso, dada a trajetória de vida e a educação recebida pelas mulheres, elas tendiam a ser mais vigiadas. Desse modo, estavam pouco sujeitas às possibilidades de transgredir as regras sociais já que eram mais privadas do convívio social. Por conseguinte, tal fato lhes favorecia quanto à exigência do atestado de idoneidade moral tanto para a admissão quanto para a permanência no magistério.

\section{PARA FINALIZAR...}

Por meio de levantamento documental realizado no Arquivo Público Mineiro, foi possível identificar quão vigorosa era a comunicação travada entre alguns segmentos da sociedade e os(as) professores(as), a Inspetoria de Instrução Pública e a administração da Província de Minas 
Gerais, com vistas à instauração do processos e à averiguação do(s) fato(s) que os originaram. Cientes de que o Governo não dava conta da fiscalização do ensino e daquilo que eles e elas faziam dentro e fora da escola, professores e professoras falsificavam mapas escolares, mantinham negócios estranhos ao magistério e cometiam outras transgressões.

Dependendo das causas, dos denunciantes e razões os desfechos dos processos sinalizam efetivamente a preocupação por parte do Governo Minério para que eles representassem ações disciplinadoras. Nesse sentido, os delitos do corpo docente que foram aqui discutidos indicam duas direções. Por um lado, eles não poderiam representar ocorrências mais frequentes e, por outro, havia a tentativa do Governo Mineiro de usar a legislação e a instauração dos processos disciplinares como estratégia para coibir comportamentos indesejados.

Para concluir a análise sobre os processos disciplinares, ratificase a discussão já realizada, ou seja, a importância que a sociedade de oitocentos atribuiu ao trabalho do(a) professor(a). Ele ou ela deveriam ser o exemplo social e, sobretudo, exemplo para as crianças. Isso exigia do(a) professor(a) esforço para que a sua vida privada não maculasse sua imagem de professor ideal. Se ele ou ela não o eram, no mínimo, deveriam esforçar-se para sê-lo. Dessa forma, qualquer comportamento contrário aos preceitos sociais punha em xeque a sua qualificação para o cargo docente.

\section{FONTES NO ARQUIVO PÚBLICO MINEIRO:}

\section{Documentos Avulsos}

IP 1/5, Caixa 02, Documento 03.

IP 1/5, Caixa 03, Documento 44.

IP 1/5, Caixa 04, Documento 38.

IP 1/7, Caixa 01, Documentos 31 e 38.

PP 1/42, Caixa 03, Documento 03.

PP 1/42, Caixa 15, Documento 10.

PP 1/42, Caixa 18, Documento 01.

PP 1/42, Caixa 21, Documento 21.

PP 1/42, Caixa 23, Documento 30.

PP 1/42, Caixa 26, Documentos 10 e 12.

PP 1/42, Caixa 28, Documentos 01 e 24.

PP 1/42, Caixa 31, Documentos 03 e 31.

PP 1/42, Caixa 33, Documento 04.

PP 1/42, Caixa 37, Documento 02.

PP 1/42, Caixa 38, Documento 23. 


\section{2- Códices}

IP 67.

IP 77.

IP 79.

SI 655.

\section{3- Legislação}

MINAS GERAIS. Decreto n. 516a, de 12-06-1891. Coleção das Leis e Decretos da Província, 1891.

MINAS GERAIS. Lei n. 13, de 29-03-1835. Coleção das Leis e Decretos da Provincia, 1835. MINAS GERAIS. Lei n. 41 de 03-08-1892. Coleção das Leis e Decretos do Estado de Minas Gerais, 1892.

MINAS GERAIS. Lei n. 77 de 19-12-1893. Coleção das Leis e Decretos do Estado de Minas Gerais, 1893.

MINAS GERAIS. Regulamento n. 44, da Lei nº. 960, de 16-12-1859. Coleção das Leis e Decretos da Provincia, 1859.

MINAS GERAIS. Regulamento n. 56, da Lei no .1267 , de 10-05-1867. Coleção das Leis e Decretos da Província, 1867.

MINAS GERAIS. Regulamento n. 62, da Lei nº 1769, de 04-04-1872. Coleção das Leis e Decretos da Provincia, 1872.

MINAS GERAIS. Regulamento n. 100, da Lei nº. 2892, 19-06-1883. Coleção das Leis e Decretos da Provincia, 1879.

MINAS GERAIS. Relatório do Presidente da Provincia José Antonio Alves de Brito, 1885. Arquivo Público Mineiro.

\section{REFERÊNCIAS}

ARIÈS, Philippe. História social da criança e da família. 2 ed. Rio de Janeiro: Livros Técnicos e Científicos, 1981.

APPLE, Michel. Trabalho docente e textos: Economia política das relações de classe e de gênero em educação. Porto Alegre: Artes Médicas, 1995.

ARROYO, Miguel. Mestre, educador, trabalhador - organização do trabalho e profissionalização. 1985. Tese (Professor Titular). Faculdade de Educação/UFMG, Belo Horizonte, 1985.

CHAMON, Magda Lúcia. Relações de gênero e a trajetória de feminização do magistério em Minas Gerais (1830-1930). 1996. Tese (Doutorado em Educação). FAE/UFMG, Belo Horizonte, 1996.

COSTA, Jurandir Freire. Ordem médica e norma familiar. Rio de Janeiro: Edições Graal, 1979.

DERMARTINI, Zeila; ANTUNES, Fátima. Magistério primário: profissão feminina, carreira masculina. Caderno de Pesquisa. n. 86, p. 5-14, agosto, 1993.

DUBAR, Claude. A socialização: construção das identidades sociais e profissionais. Porto: Porto, 1997.

DURÃES, Sarah Jane Alves. Escolarização das diferenças: qualificação do trabalho docente e gênero em Minas Gerais (1860 - 1906). 2002. Tese (Doutorado em Educação). PUC. São Paulo, 2002. 
DURÃES, Sarah Jane Alves. Acerca do valor de ser professor(a): remuneração do trabalho docente em Minas Gerais (1859-1900). Revista Brasileira de História da educação, n. 14, p. 145-176, maio/agosto, 2007.

ENGUITA, Mariano. A ambigüidade da Docência: entre o Profissionalismo e a Proletarização. Teoria e Educação, Porto Alegre, Pannonica, n. 4, p. 41-61, 1991.

FARIA FILHO, Luciano. Instrução elementar no século XIX. In: LOPES, Eliane Marta Teixeira; FARIA FILHO, Luciano; VEIGA, Cynthia Greive. (Orgs.). 500 anos de educação no Brasil. Belo Horizonte: Autêntica, 2000. p. 135-150.

FARIA FILHO, Luciano; VIDAL, Diana. Os espacos e os tempos escolares no processo de institucionalização da escola primária no Brasil, 2000. Impresso.

GONÇALVES, José Alberto. A carreira das professoras do ensino primário. In: NÓVOA, Antônio. (Org.). Vidas de professores. Porto: Porto, 1995. p. 141-169.

GOUVEA, Maria Cristina. Mestre: profissão professor(a) - processo de profissionalização docente na Província Mineira no Período Imperial. Caxambu: ANPEd, 2000.

GOUVEA, Maria Cristina; ROSA, Walquíria Miranda. A escola normal em Minas Gerais. In: Lições de Minas - 70 anos da Secretaria de Educação. Belo Horizonte: Secretaria de Educação/Governo de Minas, 2000. p. 19-31.

MACHADO, Roberto et al. Medicina social e constituição da psiquiatria no Brasil. Rio de Janeiro: Edições Graal, 1978.

MATTOS, Ilmar Rohloff de. O tempo Saguarema - a formação do Estado Imperial. 4 ed. Rio de Janeiro: Acsess, 1999.

MOACYR, Primitivo. A Instrução e as provincias: subsídios para a história da educação no Brasil. 1835-1889. São Paulo: Nacional, 1939. (Arquivo Público Mineiro).

MOURÃO, Paulo Kruger. O ensino em Minas Gerais no tempo do império. Belo Horizonte: Centro Regional de Pesquisas Educacionais, 1959.

NÓVOA, António. O passado e o presente dos professores. In: NÓVOA, António. (Org.). Profissão professor. Porto: Porto, 1991. p. 9-32.

PAIVA, Clotilde; BOTELHO, Tarcísio. População e espaço no século XIX mineiro: algumas evidências de dinâmicas diferenciadas. In: SEMINÁRIO SOBRE A ECONOMIA MINEIRA. VII. Belo Horizonte, UFMG/CEDEPLAR, 1995. p. 87-107. TEIXEIRA, Antônio Augusto. Um caso antes dos noventa. Belo Horizonte: [s.n.], 1975.

VEIGA, Cynthia Greive. A formação dos educadores: entre os mitos e a história. Educação em Revista, UFMG, Belo Horizonte, n. 15, p. 14-20, 1992.

VILLELA, Heloisa. O mestre-escola e a professora. In: LOPES, Eliane Marta Teixeira; FARIA FILHO, Luciano; VEIGA, Cynthia Greive. (Orgs.). 500 anos de educação no Brasil. Belo Horizonte: Autêntica, 2000. p. 95-150.

WARDE, Mírian Jorge. Por uma história disciplinar: psicologia, criança e pedagogia. In: FREITAS, Marcos Cezar (Org.). História social da infância no Brasil. 2 ed. São Paulo: Cortez, 1999. p. 289-310.

\section{NOTAS:}

${ }^{1}$ Mestre-escola tem sido uma denominação mais usual para os professores até meados do século XIX. Até esse período, o mestre era sinônimo de uma escola (cf. VILLELA, 2000). 
${ }^{2}$ Dada a escassez de escolas públicas, sobretudo no início do século XIX, grande número de professores, geralmente do sexo masculino, abria escolas. A permissão de criação das escolas particulares independia da licença do governo, entretanto os docentes deveriam ser habilitados, conforme proposição da legislação em vigor. Quando esses (ou essas) não comprovassem habilitação, seriam “(...) suspensos, até que habilitem, e multados pela primeira vez em cincoenta a cem mil reis, incorrendo nas reincidências em multa dobrada, além da suspensão, e da pena de quinze a sessenta dias de prisão" (Minas Gerais, Lei n. 13, art. 10, p. 28-9). Contudo, a exigência do exame concorreu para que alguns docentes abandonassem o magistério. Tal aspecto é sugerido a partir do seguinte comentário: “(...) a obrigação imposta aos mestres particulares de se habilitarem na forma da Lei para exercerem o Magistério não tem produzido ainda os bons resultados, que se esperavam. Consta pelo contrário que alguns dos que se achavam em exercício (...) fecharam as suas aulas" (Minas Gerais, Fala do presidente, 1836, p. VIII). Conforme as palavras do presidente da Província, a desistência do magistério era justificada como decorrente do fato de que eles se julgavam incapazes de obter aprovação no exame. Outros não compareceram perante os delegados ou não desejavam submeter-se à imediata fiscalização dos agentes do governo. Isso fez com que, em muitos lugares, fosse constatada a falta de aulas. Segundo a mesma legislação, o exame deveria ser realizado perante dois delegados examinadores e as matérias eram definidas a priori, escritas em cédulas, e o assunto, sorteado no momento do exame.

3 Segundo Gonçalves (1995, p. 145-6), a carreira docente das primeiras séries se constroi a partir do desenvolvimento profissional, em termos gerais, e da construção da identidade profissional. Segundo ele, o primeiro pressupõe o desenvolvimento pessoal, a profissionalização e a socialização (que implica socialização profissional ou socialização do professor); o segundo, o da construção da identidade profissional, que pressupõe a construção de representações fundadas no capital de saberes, na autonomia e no controle, pertinência cultural e social e, por último, as questões de estatuto profissional e prestígio social da função docente.

${ }^{4} \mathrm{O}$ processo de elevação à condição de funcionário público do corpo docente foi acompanhado pela profissionalização (ARROYO, 1985; NÓVOA, 1991; ENGUITA, 1991, COSTA, 1995; VILLELA, 2000). Enquanto nas sociedades ocidentais a profissionalização se iniciou por volta do século XVI, no Brasil, isso só aconteceu com o envio dos professores régios portugueses, nos séculos XVIII e XIX (VILLELA, 2000).

${ }^{5}$ Aos inspetores paroquiais cabiam, por exemplo, as funções de fiscalizar o trabalho docente e o desempenho dos alunos das escolas públicas e subvencionadas pelo menos uma vez por mês (MINAS GERAIS, Regulamento n. 62, 1872, art. 18-20, p. 8-10). Para entender mais tal atuação, cabe complementar que, nesse momento, o quadro da inspeção do ensino público e privado possuía uma hierarquia descendente que compreendia o Inspetor Geral, inspetores de comarcas e inspetores paroquiais. Segundo Paiva e Botelho (1995, p. 93-4), as “(...) freguesias, ou paróquias, eram circunscrições religiosas com algumas atribuições civis”. Todavia, foi possível identificar na legislação da instrução pública, ao longo da segunda metade do século XIX, que tal hierarquia e/ou denominações sofreram algumas variações, sobretudo ao encontro da substituição da divisão eclesiástica, em decorrência de critérios político-administrativos. 
${ }^{6}$ O Regulamento n. 44, de 1859, se esmerou ao detalhar as penalidades que deveriam ser dirigidas aos docentes das escolas públicas primárias. Alguns artigos se destinavam à prescrição de penalidades relacionadas às transgressões ocorridas nas atividades de ensino, como falsificação dos mapas escolares, excesso de castigo às crianças e abandono da escola, por exemplo. Já outros artigos contemplavam as penalidades das transgressões de ordem moral. Sobre esse tipo de transgressão, o Regulamento n. 44, de 1859, prescrevia que, se o(a) professor(a) da instrução pública fosse “(...) pronunciado por crime inafiançável ou por qualquer dos seguintes: furto, roubo, estelionato, banca-rota, adultério, incesto e rapto (...)", deveria ser destinada a ele(a) a “(...) suspensão do exercício da preceptoria sem vencimentos até que seja absolvido ou condenado, sendo que neste caso será demitido da cadeira que ocupar, ainda que esteja no período de vitaliciedade (...)” (Minas Gerais, Regulamento n. 44, 1859, art. 122, \$1 º p. 54).

${ }^{7}$ Ainda que houvesse uma tendência à progressiva entrada das mulheres como docentes no magistério primário, até 1890 a maioria era do sexo masculino (CHAMON, 1996). Precisamente no ano de 1885 havia 583 homens e 389 mulheres docentes (MINAS GERAIS, Relatório do Presidente, 1885).

${ }^{8} \mathrm{O}$ inspetor municipal era proposto pelo inspetor geral da instrução pública e nomeado pelo presidente da província. Competia a ele, entre as diferentes atividades descritas na legislação, a responsabilidade de visitar as escolas públicas e privadas pertencentes ao seu município; observar o procedimento moral civil e pedagógico dos professores e repreendê-los, quando necessário; e avaliar as condições físicas e higiênicas da escola (MINAS GERAIS, Regulamento n. 100, 1983, art. 18-20, p. 87-91).

${ }^{9}$ Segundo Mattos (1999), a diferenciação entre esses três mundos - do governo, da casa e da rua - se iniciou nos primeiros anos da sociedade imperial oitocentista e se consolidou com o projeto liberal instaurado pela República. Paulatinamente, nesse período, esses foram se tornando cada vez mais contraditórios.

${ }^{10}$ Sobre o processo brasileiro de constituição de novos espaços e tempos escolares na segunda metade do século XIX, conferir os estudos de Faria Filho (2000) e Faria Filho e Vidal (2000).

${ }^{11}$ Essa expressão foi utilizada por Arroyo (1985), em sua tese para professor titular. Acredita-se que o autor desejou chamar atenção não somente para o processo formativo do mestre, mas também para o fato de ele ensinar a habilidade do fazer. Nessa perspectiva, como Villela (2000), ele também se referia ao mestre-escola.

${ }^{12}$ Em síntese, para a configuração do processo de profissionalização é necessária a presença de três aspectos, quais sejam: “(...) especialização dos serviços que permite aumentar a satisfação de uma clientela (...)”; “(...) criação de associações profissionais que obtêm para os seus membros a proteção exclusiva dos clientes e dos empregadores que requerem o serviço do seu ofício e colocam uma linha de separação entre eles e as pessoas não qualificadas que permite aumentar o prestígio do ofício (...)”; e, por último, “(...) de constituição de uma formação específica assente num corpo sistemático de teoria que permite a aquisição de uma cultura profissional (...)" (DUBAR, 1997, p. 128, grifos do autor). 
Recebido: 21/01/2008

Aprovado: 15/09/2008

Contato:

Universidade Estadual de Montes Claros

Programa de Pós-Graduação em Desenvolvimento Social Campus Universitário Professor Darcy Ribeiro Vila Mauricéia - Montes Claros -MG Caixa Postal 126 CEP 39401-089 